\title{
EVALUATION OF ANTIBACTERIAL ACTIVITY OF 3D-PRINTING PREPARED MATERIAL USING THE JIS METHOD
}

\author{
1,2,3Karel SEHNAL, 'Dagmar UHLIROVA, 'Martina STANKOVA, ${ }^{1,2}$ Michaela VSETICKOVA, \\ ${ }^{1}$ Zuzana TOTHOVA, ${ }^{1,2,5}$ Božena HOSNEDLOVÁ, ${ }^{6}$ Marta KEPINSKA, ${ }^{1,3}$ Branislav RUTTKAY- \\ NEDECKÝ, ${ }^{4}$ Duong Ngonc BACH, ${ }^{6}$ Halina MILNEROWICZ, ${ }^{4}$ Hoai Viet NGUYEN, \\ 1,2,3,5,6René KIZEK
}

${ }^{1}$ Mendel University in Brno, Faculty of Horticulture, Department of Viticulture and Enology, Lednice, Czech Republic, EU, karelsehnal15@gmail.com

${ }^{2}$ Department of Research and Development, Prevention Medicals s.r.o., Studénka-Butovice, Czech Republic, EU, uhlirova@preventionmedicals.cz

${ }^{3}$ Department of Human Pharmacology and Toxicology, University of Veterinary and Pharmaceutical Sciences Brno, Czech Republic, EU, kizek@sci.muni.cz

${ }^{4}$ Research Center for Environmental Monitoring and Modeling, VNU University of Science, Hanoi, Vietnam, nquyenviethoai@hus.edu.vn

${ }^{5}$ Department of Food and Feed Safety, Veterinary Research Institute, Brno, Czech Republic, EU, bozena.hosnedlova@post.cz

${ }^{6}$ Department of Biomedical and Environmental Analyses, Faculty of Pharmacy with Division of Laboratory Diagnostics, Wroclaw Medical University, Wroclaw, Poland, EU, zalewska.m@gmail.com

https://doi.org/10.37904/nanocon.2019.8518

\begin{abstract}
3D printing is a modern and widely used technology that has reached virtually all sectors of human activity, from the automotive industry to medical fields. Silver nanoparticles (AgNPs) have considerable industrial potential and are intensively studied regarding their antibacterial capability. Using green synthesis, the nanoparticle surface can be coated with molecules that exhibit biologically significant properties. By combining 3D printing technology and antibacterial activity of AgNPs, a unique antibacterial material can be prepared. The aim of this work was to modify the printing filament with AgNPs, to prepare the antibacterial material by $3 \mathrm{D}$ printing and to test the antibacterial activity of the prepared material using the JIS (Japanese industrial standards) L 1902 method. Such material can be used in hospital facilities to adjust various devices to prevent nosocomial infections.
\end{abstract}

Keywords: Green synthesis, 3D printing, silver nanoparticles, antibacterial capability, infectious diseases

\section{INTRODUCTION}

Research on 3D printing technology is progressing very rapidly. In medical applications, 3D printing already occupies an irreplaceable place and is used for various purposes (Figure 1). Currently, it is possible to prepare different tissues using 3D printing [1]. Moreover, great success is the replacement of damaged bone tissues [2]. Nanoparticle research is one of the fast-developing areas of nanotechnology. Silver nanoparticles (AgNPs) are the subject of intensive studies because of their antibacterial properties [3-5]. Due to their stability, AgNPs are already widely used in several areas of industry where their antibacterial, antiviral and antifungal activities are essential. When changing $\mathrm{pH}$, AgNPs break down into ions that bind to the bacterial cell wall and produce oxygen radicals. Oxygen radicals together with silver ions interact with DNA and proteins and increase the permeability of the cell wall, thereby damaging the cell. The green synthesis uses plant extracts as reducing agents. Using this method, it is possible to modify the surface of AgNPs with biomolecules contained in the 
extracts. Due to the modification of the printing filament with AgNPs, the material with excellent antibacterial effects using 3D printing can be prepared. The indisputable advantage of the material fabricated in this way is that it is antibacterial not only on its surface but also in its entire volume.

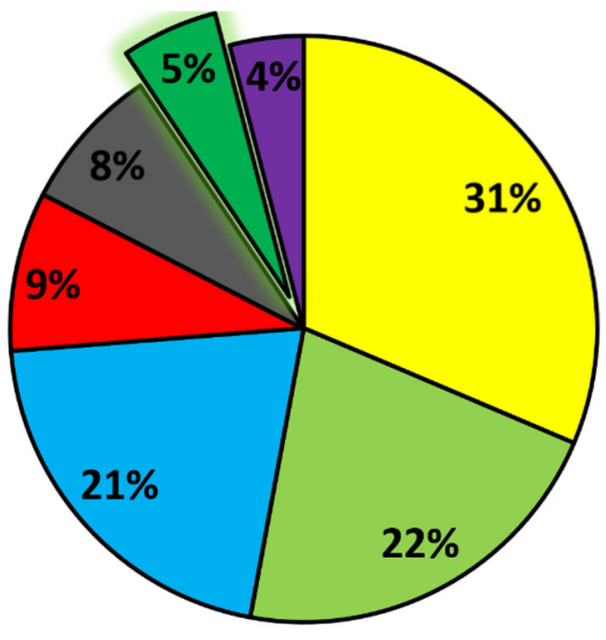

$\square 3 \mathrm{D}$ printing in additive manufacturing technology

$\square 3 D$ printing in biomaterials

$\square$ Tissue and organ printing

$\square 3 D$ printing and beyond 4D printing

$\square 3 \mathrm{D}$ printing for liver tissue engineering

$\square 3 D$ printing antibacterial material

$3 \mathrm{D}$ printing in orthopedics and traumatology

Figure 1 Graph showing the use of 3D printing. The graph was constructed based on keywords searched in the Web of Science. The found articles have been categorized and the graph was generated with the percentage of individual searched results.

\section{MATERIALS AND METHODS}

Silver nanoparticles were prepared using green synthesis, whose methodology was previously optimized. A plant extract from sage (Salvia officinalis) was used [6]. Dried plant samples were purchased from Valdemar Grešík - Natura s.r.o. The dispersion of purified AgNPs in a mixture of acetone and water (1:1) was applied to 3D printing filament (ABS - acrylonitrile-butadiene-styrene) at a concentration such that the final concentration of AgNPs in the printed material was $40 \mathrm{mg} \mathrm{AgNPs} / 1 \mathrm{~g} \mathrm{ABS}$. The density of the printed material was $30 \%$.

The Japanese Industrial Standards (JIS) L 1902 method, titled "Testing Antibacterial Activity and Efficacy on Textile Products", is designed to test the ability of fabrics that have been treated with antimicrobial agents to prevent microbial growth and to kill microorganisms, over an 18 hour period. After the mixture had dried on the filament, the material $(2 \times 2 \times 0.5 \mathrm{~cm})$ with potential antibacterial effects (Figure 2) was printed. The antibacterial activity of the material was tested using the JIS L 1902 method.

The bacterial suspension of Staphylococcus aureus in LB medium was diluted to an optical density of OD = $0.035\left(\mathrm{c}=1 \times 10^{7} \mathrm{CFU} / \mathrm{mL}\right) .83 \mu \mathrm{L}$ of the diluted suspension was mixed with $917 \mu \mathrm{L}$ of a sterile solution of PBST. $30 \mu \mathrm{L}$ of the suspension was pipetted onto the test material $(2 \times 2 \mathrm{~cm})$. The material with the suspension was covered with sterile parafilm $(1.5 \times 1.5 \mathrm{~cm})$. Then, it was placed on a sterile Petri dish that was covered and the bacteria were allowed to incubate in an incubation box $\left(35^{\circ} \mathrm{C}\right)$ for 24 hours. On next day, the material with parafilm was placed in a tube with $10 \mathrm{~mL}$ of PBS-T. Subsequently, it was allowed to vortex for 1 minute to separate the bacteria from the material into the mixture. To increase the detection limit, the mixture was centrifuged (14000 g, $2 \mathrm{~min}$ ) and diluted 10x, 100x, and 1000x in PBS-T. Then, $50 \mu \mathrm{L}$ of the mixture was pipetted onto a Petri dish. On day 3, the number of grown colonies from a bacterial suspension that was cultured on modified and unmodified material was compared. The experiment was performed in three replicates. Three identical printed AgNPs-modified platforms (AgNPs+) and three equal printed AgNPsunmodified platforms (AgNPs-) were tested. The scheme of the method is summarized in Figure 2. 


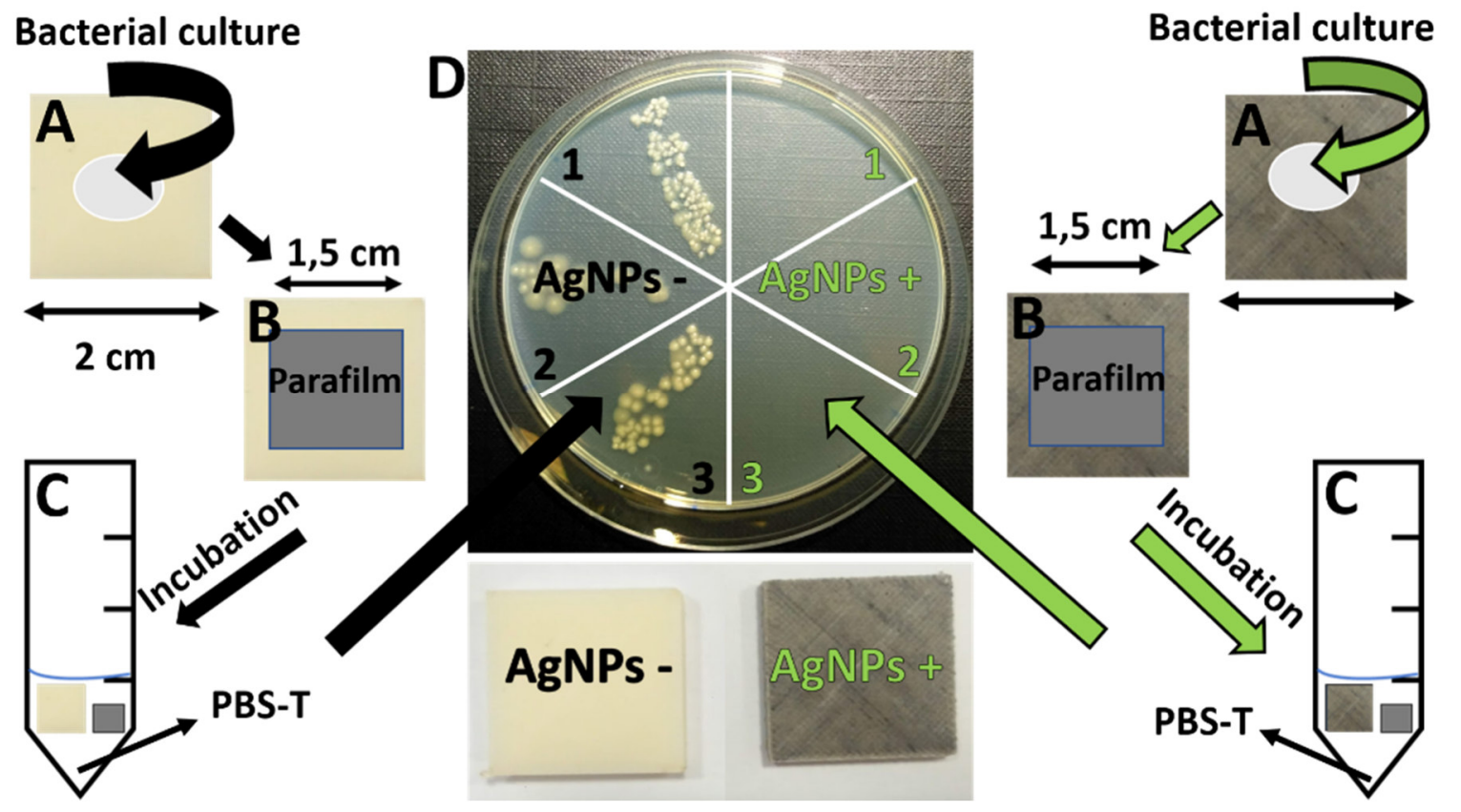

Figure 2 Scheme of the JIS L 1902 antibacterial test. Comparison of the antibacterial effect of modified and unmodified material. (A) Application of bacterial suspension of $S$. aureus on the material. (B) Covering the suspension with parafilm. (C) The placement of the material with parafilm in PBS-T solution after incubation, vortexing, and centrifugation. (D) Applying the mixture to a Petri dish (3 replicates). Bacterial suspension used in the Petri dish was 30x diluted, AgNPs-modified platforms (AgNPs+), AgNPs-unmodified platforms (AgNPs-).

\section{RESULTS AND DISCUSSION}

The surface of AgNPs was characterized by biochemical methods. The high-resolution transmission electron microscopy and the hydrodynamic light scattering were used to determine AgNPs sizes (average size of AgNPs was $40 \mathrm{~nm}$ ). The absorption maximum was found at $450 \mathrm{~nm}$. Several shapes and sizes of AgNPs in the prepared mixture have been demonstrated by density gradient centrifugation and gel electrophoresis. It is known that the shape and size of AgNPs affect antibacterial activity [7]. The prepared nanoparticles were subsequently studied for changes in the biochemical profile in S. aureus [8]. We found that AgNPs affected the metabolism of xylose (decrease by more than $50 \%$ ), trehalose (decrease by more than $30 \%$ ), arabinose (decrease by $80 \%$ ), and ribose (decrease by $75 \%$ ). The data indicate that the rate of glycolysis was affected. Thus, the bacterium increases the energy gain that probably uses for the defence mechanisms removing AgNPs from cells. In addition, AgNPs also affects the pentose cycle and increases the metabolism of sugars. Moreover, changes in amino acid metabolism, a reduction in glutamine production of an average change of about $35 \%$, were noted. The effect on urea cycle metabolism was about $25 \%$. The experimental work clearly shows the significant effect of AgNPs on a wide range of metabolic processes in bacterial cells. Thus, the process of developing bacterial cell resistance to AgNPs is more limited.

After evaluation of the JIS L 1902 test, the excellent antibacterial activity of the prepared material against $S$. aureus was proved. The number of bacterial colonies observed on the Petri dish was evaluated. In areas of application of bacterial suspension that was then cultured on the modified material $\left(\mathrm{AgNPs}^{+}\right)$, a very marked growth inhibition was observed compared to the control (AgNPs). Bacterial colonies on the AgNPs ${ }^{+}$material were observed only when the undiluted suspension was applied to a Petri dish. Of three repetitions, on average, only 5 colonies grew up. For further dilutions, no further colonies were observed in AgNPs ${ }^{+}$. 


\section{CONCLUSION}

Silver nanoparticles were prepared using a green synthesis approach. Nanoparticles prepared using sage extract showed strong antibacterial activity. Dispersed AgNPs were applied to the printed 3D filament and the material obtained was tested for antibacterial activity using JIS L 1902 test. Antibacterial activity was tested on the Gram-positive bacteria S. aureus. It has been proven that the prepared material exhibited excellent antibacterial activity. Silver nanoparticle-modified material could be used in hospital facilities to eliminate nosocomial infections.

\section{ACKNOWLEDGEMENTS}

The work was carried out with the support of the H2020 CA COST Action CA15114, INTER-COST LTC18002.

\section{REFERENCES}

[1] CAPEL, A. J., RIMINGTON, R. P., LEWIS, M. P.,CHRISTIE, S. D. R. 3D printing for chemical, pharmaceutical and biological applications. Nature Reviews Chemistry, 2018, vol. 2, no. 12, pp. 422-436.

[2] TURNBULL, G., CLARKE, J., PICARD, F., RICHES, P., JIA, L. L., HAN, F. X., LI, B.,SHU, W. M. 3D bioactive composite scaffolds for bone tissue engineering. Bioactive Materials, 2018, vol. 3, no. 3, pp. 278-314.

[3] AHMAD, S., MUNIR, S., ZEB, N., ULLAH, A., KHAN, B., ALI, J., BILAL, M., OMER, M., ALAMZEB, A., SALMAN, S. M.,ALI, S. Green nanotechnology: a review on green synthesis of silver nanoparticles - an ecofriendly approach. International Journal of Nanomedicine, 2019, vol. 14, no. pp. 21.

[4] BAGHAYERI, M., MAHDAVI, B., ABADI, Z. H. M.,FARHADI, S. Green synthesis of silver nanoparticles using water extract of Salvia leriifolia: Antibacterial studies and applications as catalysts in the electrochemical detection of nitrite. Applied Organometallic Chemistry, 2018, vol. 32, no. 2, pp. 9.

[5] FERNANDEZ, A., SORIANO, E., HERNANDEZ-MUNOZ, P.,GAVARA, R. Migration of Antimicrobial Silver from Composites of Polylactide with Silver Zeolites. Journal of Food Science, 2010, vol. 75, no. 3, pp. E186-E193.

[6] GERICKE, S., LUBKEN, T., WOLF, D., KAISER, M., HANNIG, C.,SPEER, K. Identification of New Compounds from Sage Flowers (Salvia officinalis L.) as Markers for Quality Control and the Influence of the Manufacturing Technology on the Chemical Composition and Antibacterial Activity of Sage Flower Extracts. Journal of Agricultural and Food Chemistry, 2018, vol. 66, no. 8, pp. 1843-1853.

[7] PANACEK, A., KVITEK, L., PRUCEK, R., KOLAR, M., VECEROVA, R., PIZUROVA, N., SHARMA, V. K., NEVECNA, T.,ZBORIL, R. Silver colloid nanoparticles: Synthesis, characterization, and their antibacterial activity. Journal of Physical Chemistry B, 2006, vol. 110, no. 33, pp. 16248-16253.

[8] GILL, S. R., FOUTS, D. E., ARCHER, G. L., MONGODIN, E. F., DEBOY, R. T., RAVEL, J., PAULSEN, I. T., KOLONAY, J. F., BRINKAC, L., BEANAN, M., DODSON, R. J., DAUGHERTY, S. C., MADUPU, R., ANGIUOLI, S. V., DURKIN, A. S., HAFT, D. H., VAMATHEVAN, J., KHOURI, H., UTTERBACK, T., LEE, C., DIMITROV, G., JIANG, L. X., QIN, H. Y., WEIDMAN, J., TRAN, K., KANG, K., HANCE, I. R., NELSON, K. E.,FRASER, C. M. Insights on evolution of virulence and resistance from the complete genome analysis of an early methicillinresistant Staphylococcus aureus strain and a biofilm-producing methicillin-resistant Staphylococcus epidermidis strain. Journal of Bacteriology, 2005, vol. 187, no. 7, pp. 2426-2438. 